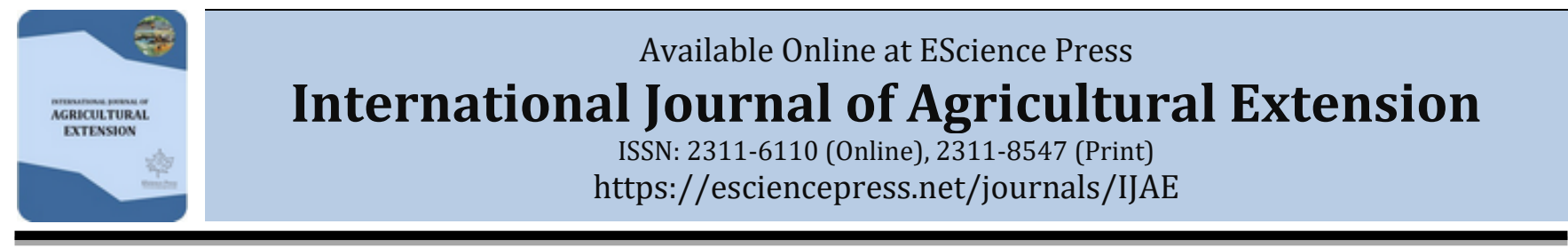

\title{
ASSESSMENT OF COFFEE (COFFEA ARABICA L.) GENETIC EROSION AND GENETIC RESOURCES MANAGEMENT IN ETHIOPIA
}

\author{
Afework Legesse \\ Ethiopian Institute of Agriculture Research, Jimma Agriculture Research Center, P. O. Box 192, Jimma, Ethiopia.
}

*Corresponding Author Email: Afework.legesse@yahoo.com

\section{A B S T R A C T}

Coffee is an important source of annual income and employment contributing significantly to the economies of many developing countries. Ethiopia is the center of origin and diversity of Coffea arabica L., there is immense genetic variability that offers great potential for improvement of the crop. The objective of this paper is to assess the status of Coffee genetic diversity, identify major factors that cause coffee genetic erosion and status of coffee genetics resources management in Ethiopia. The presences of high genetic diversity in wild Coffea arabica in Ethiopia were reported by different authors. However, the genetic diversity of coffea arabica L. are being lost rapidly due to several factors such as human population pressures leading to conversion of land to agriculture, deforestation and land degradation; low coffee prices leading to abandoning of coffee trees in forests and gardens and shifting cultivation to other more remunerative crops; and climate change. Additionally, narrow genetic basis of commercially used Arabica coffee cultivars and increased incidence of pests and diseases associated with climate change is leading to significant crop losses, threatening livelihoods in many coffee growing countries. Therefore, Conserving the wild Arabica coffee gene pool and its evolutionary potential present in Ethiopia is critically important for maintaining coffee yield, disease resistance, drought tolerant, quality and other important traits in future breeding program.

Keywords: Coffee, collection, germplasm, genetic diversity, variety.

\section{INTRODUCTION}

Coffee belongs to the family Rubiaceae and the genus Coffea. All Coffea species are native to the tropical forests of Africa, Madagascar and islands of the Indian Ocean (Mascarene islands), while species of Psilanthus are found in Asia and tropical Africa (Bridson \& Verdcourt, 1988). The genus Coffea comprises of nearly 124 well identified species; however, Coffea arabica L. and Coffea canephora P. are the two commercially important species (Davis et al., 2006; Gray et al., 2013). These two species are economically important for the production of the beverage coffee, C. arabica L. and $C$. canephora A. Froehner (Davis et al., 2006). Higher beverage quality is associated with C. arabica (Lashermes et al., 1999). Coffea arabica is a self-fertile tetraploid $(2 \mathrm{n}=4 \mathrm{x}=44)$, whereas all other Coffea species are diploid $(2 \mathrm{n}=2 \mathrm{x}=22)$ and are mostly self-sterile (Pearl et al., 2004). Coffee is the most important agricultural commodity which stands second next to oil in terms of international trading in the global market. In many coffee producing countries, besides contributing a tremendous amount to the foreign exchange as a cash crop, it serves as a means of livelihood for millions of people and plays a vital role in uplifting socio-economic values (Orozco et al., 1994; Carneiro, 1999; Anthony et al., 2001; Stieger et al., 2002). Global production of Coffea arabica during 2016 was recorded 5.712 million ton (ICO, 2016). Brazil, the leading coffee producing country, accounts for $40 \%$ of the global coffee supply and Vietnam, the second largest coffee producer, accounts for roughly $20 \%$ of the world coffee production. Ethiopia remains the largest producer of coffee in Africa and graced as fifth largest coffee producer in the world next to Brazil, Vietnam, Colombia, and Indonesia, contributing to about $4.2 \%$ of the total world coffee production (ICO, 2015). According to the report of CSA (2017), estimated area of land covered by coffee in Ethiopia is about 700474.69 ha, whereas the 
estimated annual national production of clean coffee is about 469091.12 tons with average productivity of $669.6 \mathrm{~kg} \mathrm{ha}^{-1}$. The sustainability of the coffee industry and continuous improvement of the crop for potential yield, quality, disease resistance, tolerance to moisture stress, and any other desirable traits solely depends on the amount of genetic diversity available in the hands of the breeders or in the original population. Currently, the indigenous Coffee genetic resources of Ethiopia are becoming endangered owing to the high rate of genetic erosion resulting from biotic, a biotic and socioeconomic factor. Moreover, limited attention has been given to assess the diversity and conservation of indigenous coffee genetic resources. As a result, some of indigenous coffee genetic resources in Ethiopia are endangered, even they may be lost before they characterize and conserve (Gole et al., 2002). Availability of genetic diversity is necessary to coffee improvement programmes. Despite such immense contribution of genetic diversity, much attention has not been given to the conservation and sustainable use of coffee genetic resources. Accordingly, this review was designed, to assess the status of Coffee genetic diversity, identify major factors that cause coffee genetic erosion and status of coffee genetics resources management in Ethiopia.

Center of Origin and Diversity of Coffee: Among 124 Coffea species in the genus Coffea; Coffea arabica is the only species occurring in Ethiopia and geographically isolated from the rest Coffea species and naturally restricted in to two isolated mountain forests on the western and eastern sides of the Great Rift Valley in Ethiopia (Mayer 1968; Bridson \& Verdcourt 1988; Gole et al., 2003). Ethiopia holds a unique position in the world as Coffea arabica L. as its primary centre of diversity in the south-western highlands of the country. This fact is strongly substantiated by observations and publications of travellers and scientists (Vavilov 1935; Sylvain 1955; Harlan 1969).

Investigation on the national coffee collections from Keffa, Shakka, Bench maji, Ilubabor, Jimma and Anfillo areas available at Melko for yield, tree morphology, degree of reaction to diseases and pests and the inherent quality also indicated the existence of tremendous variability for these characteristics. Particularly the finding of significant number of highly resistant coffee lines to coffee berry disease (CBD) and other diseases and pests confirms the existence of large genetic variability of coffee in Ethiopia (Poulus \& Demil, 1999). Moreover several phenotypic and molecular studies revealed that the populations of $\mathrm{C}$. arabica from the southwestern part of Ethiopia have high genetic variability (Montagnon \& Bouharmont, 1996; Lashermes et al., 1996; Anthony et al., 2001; Mesfin \& Bayetta, 2008; Olika et al., 2011; Getachew et al., 2013; Lemi \& Ashenafi, 2016). Different scholars reported presence of high coffee genetic diversity in Ethiopia, which is mainly attributed to its diverse ecological features such as suitable altitude, ample rainfall, optimum temperature, fertile soils etc. and the presence of indigenous methods of coffee production system in the country (Yeshitila et al., 2004; Gole et al., 2001). Esayas (2005), on his study on forest coffee tree populations indicate that moderate genetic diversity exists within and among few forest coffee populations, which need due attention from a conservation and breeding point of view. Comparatively, higher genetic diversity has been reported among wild coffee populations than within cultivated genotypes (Aga et al., 2003).

Genetic Erosion and its Causes: Genetic erosion is defined as the loss of variability from crop populations in diversity centers, i.e. areas of domestication and secondary diversification (Brush, 1999). According to Guarino (1998) genetic erosion as a permanent reduction in richness or evenness of common localized genes or alleles or the loss of combination of alleles over time in a defined area. The wild and cultivated forms of coffee genetic resources residing in the tropical rainforests and farmers' field are under severe threat from genetic erosion owing to a combination of factors such as deforestation, replacement of the landraces by improved cultivars, recurrent drought and land degradation, competition by other crops and minimal conservation efforts (Branson, 2008; Hennig, 2008).

The genetic diversity existing in Ethiopia, particularly the wild genepools, is presently subject to serious genetic erosion and irreversible losses. Some of these factors are related to socio-economic factors in general, while others are related to biotic and a biotic factor (Worede, 1997; Gole et al., 2002; Osorio, 2002). The most crucial factors for genetic erosion in the country include displacement of farmers' varieties by new, genetically uniform crop cultivars, changes and development in agriculture or land use, destruction of habitats and ecosystems, and drought (Worede, 1997). The population growth results in increasing land 
pressure and conversion of forest to farmland. The situation is also being exacerbated by population migration policies and government settlement programs for food security reasons. According to FAO (2010) report, Ethiopia lost an average of 141,000 hectares of forest per year between 1990 and 2000 with an average annual deforestation rate of $0.97 \%$. Between 2005 and 2010, the rate of forest change increased by $1.11 \%$ per annum. In total, between 1990 and 2005, Ethiopia lost $14.0 \%$ of its forest cover, or around 2,114,000 hectares.

In some areas, high market preference is also another factor for contribution of genetic erosion. The interest of farmers in coffee growing decreased, due to very low prices paid to farmers, resulted in the decrease of producers' revenues and shifting to food crops or to the more lucrative khat cultivation after uprooting coffee plants (Gole et al., 2002; Osorio, 2002).

There is also Changing climatic conditions resulted in development of new diseases and pests and the loss of adaptation of some formerly high yielding crop landraces, forcing farmers to shift to new and better adapted landraces (Sadhan \& Dipak, 2016). The replacement of local landraces by few improved varieties with a narrower genetic base was encouraging genetic erosion (Ameha, 1991). The incidence of coffee wilt disease or tracheomycosis caused by Gibberella xylarioides, which destroys coffee plants, is also increasing in the country, mainly in the garden coffee systems (Girma et al., 2001).

Germplasm Collection and Conservation: Interest in coffee genetic resources increased during the second half of the 20th century, as breeders became aware that deforestation was causing the erosion of coffee habitats, thereby threatening coffee genetic resources. It was estimated that the closed high forest in Ethiopia had declined to only $18 \%$ by 1997 , which represents a loss of $60 \%$ in less than 30 years (Gole et al., 2002). Considering the socio-economic importance of C. arabica cultivation, two large surveys were organized in Ethiopia: by FAO in 1964-65 (Fernie et al., 1968) and by ORSTOM (now IRD) in 1966 (Guillaumet \& Hallé 1978). Collecting of other species started at the same period in the Madagascar region through a joint initiative of the Paris Museum of Natural History, CIRAD and ORSTOM. In Africa, survey missions were conducted in seven countries between 1975 and 1987 by ORSTOM. Lastly, a mission was organized by IPGRI in Yemen (Eskes, 1989), an area considered to be the first centre of dispersion for $\mathrm{C}$. arabica outside Ethiopia (Meyer, 1965).

In Ethiopia since, the establishment of Jimma Research Station (now the Jimma Agricultural Research Centre) in 1967 that systematic and organized coffee research and germplasm collecting started at the national level. The collection arising from the ORSTOM mission at the end of 1966 was successfully established at the Melko station near Jimma and called the 'French Collection'. Since that date, 47 other collecting missions have been conducted over the last 40 years by JARC researchers within Ethiopia and, in total, 6,721 samples indigenous and exotic coffee accessions are collected and conserved at field gene bank (Table 1). Those genetic resources is ensured in the form of living collections at the main JARC centre near Jimma and at 9 other sub-centres or testing sites, which are mostly located in the main coffee producing zones under different agro-ecological conditions. Large number of these accessions were evaluated for yield, disease and insect pest resistance/tolerance, overall quality and other traits of breeding interest while the remaining are currently under evaluation. Accordingly, large number of promising accessions were selected and utilized in the breeding program for variety development. The coffee germplasms maintained at JARC gene bank initiated with the aim of: the search for traits immediately usable in the breeding programme, such as CBD resistance; intended to capture the genetic diversity existing in the different agroecologies of Ethiopia; and designed to rescue coffee tree populations threatened by erosion (Labouisse et al., 2008). Maintenance of all accessions including CBD resistant selections collected during the crash program and assembling new collections is still underway as a major coffee breeding activity in the center (Labouisse, 2006; Tadesse, 2017).

In addition to coffee genetic resource conservation by JARC, there is also a large field genebank established and managed by the IBC. It is located in Choche (Limu) and, in 2006, contained 5,196 accessions maintained under indigenous trees shade covering an area of 40 ha (Labouisse et al., 2008). This gene bank is mainly geared towards the conservation of diversity of 'wild coffee'. It consists of samples collected at random from forests or semi-forests and some accessions are duplicates of JARC collections. IBC maintains another small coffee field genebank in Bedesa (West Harerge) with coffee samples collected in Harerge area.

In an attempt to halt the loss of biodiversity and 
conserve the last remaining coffee forests in Ethiopia, two biosphere reserves became part of the United Nations World Network of Biosphere in 2010. The Yayu Coffee Forest Biosphere Reserve, located in southwestern Ethiopia, is one of the last remaining montane rainforest fragments with wild C. arabica populations in the world (UNESCO, 2014a). The Kaffa Biosphere Reserve is located within the East Afromontane Biodiversity Hotspot with a focus on the protection of $\mathrm{C}$. arabica genetic resources and its associated ecosystems (UNESCO, 2014b).

Table 1. Summary of Arabica coffee germplasm collections maintained at field gene bank of JARC.

\begin{tabular}{lcc}
\hline Type of collection & Year of collection & Number of accessions \\
\hline French mission collections and SN series & 1966 & 73 \\
CBD resistant selections & $1973-1975$ & 696 \\
CBD resistant selections* & $1981-1987$ & 568 \\
National coffee collections & $1970-1990$ & 554 \\
National coffee collections** & $2004-2009$ & 941 \\
Sub-total & 2832 & \\
International coffee collection & $1968-1984$ & 190 \\
Local landrace coffee collections*** & $1994-2013$ & 3699 \\
Total coffee genetic resource & 6721 & \\
\hline
\end{tabular}

* - Selections after the discontinuation of the 1st crash-program.

** - Collected under the local landrace variety development program but planted outside their origin.

*** - Collections under local landrace variety development program and planted at their place of origin.

Germplasm Conservation Strategy: For Coffea, research in the in situ conservation of genetic resources has lagged behind compared to developing methods for ex situ conservation (Engelmann \& Dulloo, 2007). Conservation efforts of Coffea germplasm in its natural habitats have been very limited (Engelmann \& Dulloo, 2007). Coffee seeds are recalcitrant or exhibit intermediate storage behavior, making preservation of germplasm through seed banking problematic (Dulloo et al., 1998). Hence, complementary conservation strategies are essential for effective and sustainable conservation of the maximum range of genetic diversity (Dulloo et al., 1998) to include in situ and ex situ conservation strategies.

More studies are required on coffee trees populations to determine the local abundance, the self-fertilization rate, the population age structure, the degree of kinship between individuals, the phenotypic diversity (morphology, resistance to diseases), and the genetic polymorphism. Such studies have been undertaken on wild populations of Coffea canephora Pierre and Coffea liberica Hiern (Berthaud, 1986) but much remains to be done on Coffea arabica, in both its forest habitat and in the gardens. This will help to determine the optimum size of the populations to be maintained for in situ/on- farm conservation, and to define an appropriate sampling strategy (number and location of sampling sites, number of individual plants sampled at a site, etc.) for ex situ conservation (Brown \& Marshall, 1995). As regards in situ conservation policy, there is a need to review the lessons from the past and current forest management projects in Ethiopia and in other countries. This was the main objective of the workshop entitled 'Policies to increase forest cover in Ethiopia' organized in September 2007 by the Environmental Economics Policy Forum for Ethiopia (Bane et al., 2008). The following major strategies could play the most important role to enhance the conservation of coffee genetic resources: funding of in situ and ex situ conservation, establishment of property rights and establishment of germplasm exchange agreement (Richerzhagen \& Virchow, 2002; USDA, 2008).

\section{CONCLUSION AND RECOMMENDATIONS}

Coffee is one of the most important crops with significant economic impacts on both producing and consuming countries. A large amount of coffee genetic diversity has been collected and introduced into field gene banks. However, it has been observed that the coffee genetic resources being conserved in living collections (or field gene banks) are quickly eroding, due 
to a multitude of reasons, including adaptability problems, vandalism, natural catastrophes and above all insufficient funds for maintaining the collections. There is an urgent need to place the conservation of coffee genetic resources on more secure grounds, and to establish a global strategy for a more efficient and costeffective rational conservation of these precious resources. Conserving genetic resources in the field is indispensable for evaluating them. However, field gene banks appear to be very vulnerable to local hazards and consequences of global climatic change, as well as from financial resource constraints. As genotypic selection and genetic drift occur in coffee genetic resources maintained ex-situ, research efforts have been focused on the development of a cryopreservation method as a complementary conservation measure, in order to overcome the limitations of field conservation.

\section{REFERENCES}

Aga, E., Bryngelsson T., Bekele E., \& Salomon B., (2003). Genetic diversity of dom amplified polymorphic DNA (RAPD) analysis. Hereditas, 138, 36-46.

Ameha, M., (1991). Significance of Ethiopian coffee genetic resources to coffee improvement. In: Engels JMM, Hawkes J, Worede M (eds) Plant genetic resources of Ethiopia. Cambridge University Press, Cambridge, pp 354-359

Anthony, F., Bertrand B., Quiros 0., Wilches A., Lashermes P., Berthaud J., \& Charrier A., (2001). Genetic diversity of wild coffee (Coffea arabica L.) using molecular markers. Euphytica, 118, 53-65.

Bane, J., Nune S., Mekonnen A., \& Bluffstone R., (2008). Policies to increase forest cover in Ethiopia. Proceedings of a policy workshop organized by Environmental Economics Policy Forum for Ethiopia (EEPE), 18-19 September 2007. Ethiopian Development Research Institute, Addis Ababa.

Berthaud, J., (1986). Les ressources ge 'ne 'tiques pour l'ame 'lioration des cafe 'iers africains diplor "des : e 'valuation de la richesse ge 'ne 'tique des populations sylvestres et de ses me 'canismes organisateurs. Conse 'quences pour l'application. ORSTOM, Paris.

Branson, J., (2008). De-forestation of African rainforests. Bridson, D.M., \& Verdcout B., (1988). Rubiaceae, Part 2. In: Polhill R.M., (ed.), Flora of Tropical East Africa. Balkema, Rotterdam, the Netherlands, pp. 703727.
Brown, A.H.D., \& Marshall DR, (1995). A basic sampling strategy: theory and practice. In: Guarino L, Rao VR, Reid $R$ (eds) Collecting plant genetic diversity. Technical guidelines. IPGRI, CAB International, Wallingford, UK, pp 75-91

Brush S., (1999). Genetic Erosion of Crop Populations in Centres of Diversity: A Revision. In: Serwinski, J. \& Faberova, I. (Eds.). Proceedings of the Technical Meeting on the Methodology of the FAO World Information and Early Warning Systems on Plant Genetic Resources. Research Institute of Crop Production, Prague Czech Republic, FAO.

Carneiro, M.F. (1999). Advances in coffee biotechnology. AgBiotechNet, 1,1-8.

Charrier A., \& Berthaud J., (1985). Botanical classification of coffee. In: Clifford M.N. and Wilson K.C. (eds.), Coffee Botany, Biochemistry and Production of Beans and Beverage, Croom Helm, London, pp. 13-47.

CSA (Central statistical authority), (2017). Agricultural sample survey report on area, production and yields of major crops. Central statistical Authority, Addis Ababa, Ethiopia.

Davis, A.P. (2011). Psilanthus mannii, the type species of Psilanthus transferred to Coffea. Nordic Journal of Botany, 29, 471-472.

Davis, A.P., Govaerts, R., Bridson, D.M., \& Stoffelen, P. (2006). An annotated taxonomic conspectus of the genus Coffea (Rubiaceae). Botanical Journal of the Linnean Society, 152(4), 465-512.

Dulloo, M.E., Guarino L., Engelmann F., Maxted N., Newbury J.H., Attere F. \& Ford-Lloyd, B.V., (1998). Complementary conservation strategies for the genus Coffea: a case study of Mascarene Coffea species. Genet. Genetic Resources and Crop Evolution, 45, 565-579.

Engelmann. F. \& Dulloo E., (2007). Introduction in conserving coffee genetic resources: complementary strategies for ex situ conservation of coffee (Coffea arabica L.) genetic resources. A case study in CATIE, Costa Rica, F. Engelmann, M.E. Dulloo, C. Astorga, S. Dussert and F. Anthony (eds.), (Rome, Italy: Bioversity International), pp.1-11.

Esayas, A., (2005). Molecular Genetic Diversity Study of Forest Coffee Tree [Coffea arabica L.] Populations in Ethiopia: Implications for Conservation and 
Breeding. Doctoral thesis, Swedish University of Agricultural Sciences.

Eskes, A.B., (1989). Identification, description and collection of coffee types in P.D.R. Yemen. Technical report [from IRCC/CIRAD to IBPGR] of the IBPGR/PDR Yemen Ministry of Agriculture/IRCC-CIRAD mission to Yemen PDR, 15 April-7 May 1989. IBPGR (now Bioversity International) internal report.

FAO, (2010). Global forest resource assessment 02010 main report.

Fernie, L.M., Greathead D.J., Meyer F.G., Monaco L.C. \& Narasimhaswamy R.L., (1968). FAO coffee mission to Ethiopia, 1964-65. FAO, Rome, Italy. p204.

Getachew, W., Sentayew A., Taye K. \& Tadesse B., (2013). Genetic diversity analysis of some Ethiopian specialty coffee (Coffea arabica L.) germplasm accessions based on morphological traits. Time Journal of Agriculture and Veterinary Science, $1(4), 47-54$.

Girma, A., Hulluka M. \& Hindorf H., (2001). Incidence of tracheomycosis, Gibberella xylarioides (Fusarium xylarioides) on Arabica coffee in Ethiopia. Journal of Plant Disease and Protection, 108(2), 136142

Gole, T., W.M. \& Teketay, D., (2001). The forest coffee ecosystems: ongoing crises, problems and opportunities for gene conservation and utilization. In: Imperative Problems Associated with Forestry in Ethiopia, Biological Society of Ethiopia, Pp 131-142.

Gole, T.W., (2003). Vegetation of the Yayu forest in SW Ethiopia: impacts of human use and implications for in situ conservation of wild Coffea arabica L. populations. Ecoloyg and Development Series, No.10, Zentrum fur Entwicklungsforschung, Center for Development Research, University of Bonn.

Gole, T.W., Denich M., Teketay D. \& Vlek PLG, (2002). Human impacts on the Coffea Arabica genepool in Ethiopia and the need for its in situ conservation. In: Engels JMM, Rao VR, Brown AHD, Jackson MT (eds) Managing plant genetic diversity. CABI Publishing, Oxon, pp 237-247

Gray, Q., A. Tefera \& T. Tefera, (2013). Ethiopia: Coffee Annual Report. GAIN Report No. ET, 1302.

Guarino, L., (1998). Approaches to Measuring Genetic
Erosion. Presented at the International workshop on developing institutional agreements \& capacity to assist farmers in disaster situations to restore agricultural systems \& seed security activities. Rome, Italy, FAO.

Guillaumet, J.L. \& Hallé F., (1978). Echantillonnage du matériel récolté en Ethiopia. Bulletin IFCC, 14,13-18.

Guyot, R., De la Mare, M., Viader, V., Hamon, P., Coriton, 0., Bustamante-Porras, J. \& De Kochko, A. (2009). Microcollinearity in an ethylene receptor coding gene region of the Coffea canephora genome is extensively conserved with Vitis vinifera and other distant dicotyledonous sequenced genomes. BMC plant biology, 9(1), 22.

Harlan, J. R., (1969). Ethiopia: a center of diversity. Economic Botany, 23, 309-314.

Hennig, R.C. (2008). Forests \& deforestation in Africathe wasting of an immense resource. Afrol, News.

International Coffee Organization (ICO), (2015). Trade Statistics: Total Production of Exporting Countries. http://www.ico.org/prices/po.htm. Accessed August 1, 2015.

Labouisse J.P., (2006). Summary of passport data of coffee germplasm maintained at JARC. Ethiopian Institute of Agricultural Research, Jimma.

Labouisse, J. P., Bellachew, B., Kotecha, S., \& Bertrand, B. (2008). Current status of coffee (Coffea arabica L.) genetic resources in Ethiopia: implications for conservation. Genetic Resources and Crop Evolution, 55(7), 1079.

Lashermes, P., Trouslot P., Anthony F., Comes M.C. \& Charrier A., (1996). Genetic diversity for RAPD markers between cultivated and wild accessions of Coffea arabica. Euphytica, 87, 59-64.

Lemi, B. \& Ashenafi A., (2016). Genetic Variability, Heritability and Genetic Advance for Yield and Yield Components of Limmu Coffee (Coffea arabica L.) accessions in South Western Ethiopia. Middle-East Journal of Scientific Research, 24(6), 1913-1919.

Mesfin K. \& Bayetta B., (2008). Phenotypic Diversity in the Hararge Coffee (Coffea arabica L) Germplasm for Quantitative Traits. East African Journal of Sciences, 2(1), 13-18.

Meyer, F.G. (1968). Further observation on the history and botany of the Arabica coffee plant, Coffea arabica L., in Ethiopia. FAO Mission to Ethiopia 
1964-65, Rome.

Montagnon, C., \& Bouharmont, P. (1996). Multivariate analysis of phenotypic diversity of Coffea arabica. Genetic Resources and Crop Evolution, 43(3), 221-227.

Olika, K., Sentayehu A., Taye K. \& Weyessa G., (2011). Variability of quantitative Traits in Limmu Coffee (Coffea arabica L.) in Ethiopia. International Journal of Agricultural Research, 6, 482-493.

Orozco-Castillo C., Chalmers K.J., Waugh R. \& Powell W., (1994). Detection of genetic diversity and selective gene introgression in coffee using RAPD markers. TAG Theoretical and Applied Genetics, 87(8), 934-940.

Osorio, N., (2002). The global coffee crisis: a threat to sustainable development. ICO report. Submitted to the World Summit on Sustainable Development, Johannesburg.

Paulos, D. \& Demil T., (1999). The need for forest coffee germplasm conservaton in Ethiopia and its significance in the control of coffee diseases. In: Proceedings of the Workshop on Control of Coffee Berry Disease (CBD) in Ethiopia. pp. 125135.

Pearl, H. M., Nagai, C., Moore, P. H., Steiger, D. L., Osgood, R. V., \& Ming, R. (2004). Construction of a genetic map for arabica coffee. Theoretical and Applied Genetics, 108(5), 829-835.

Richerzhagen, C. \& Virchow D., (2002). Sustainable utilization of crop genetic diversity through property right mechanisms? the case of coffee genetic resources in Ethiopia. BioEcon workshop,
May 30-31, 2002.

Sadhan, K.R. \& Dipak, R. (2016). Use of Medicinal plants and its Vulnerability due to climate change in Northern part of Bangladesh. American Journal of Plant Sciences, 7, 1782-1793.

Steiger, D.L, Nagai C, Moore PH, Morden CW, Osgoog RV \& Ming R., (2002). AFLP analysis of genetic diversity within and among Coffea arabica cultivars. Theory of Applied Genetics, 185,189215.

Sylvain P.G. (1955). Some observations on Coffea arabica L. in Ethiopia. Turrialba, 5(1-2), 37-53.

Tadesse, B. (2017). Progress in Arabica Coffee Breeding in Ethiopia: Achievements, Challenges and Prospects. International Journal of Sciences: Basic and Applied Research (IJSBAR,), 33(2), 1525.

Vavilov, N.I., (1935). Origin and geography of cultivated plants. In: The phytogeographical basis for plant breeding. Cambridge Univ. Press, Cambridge, pp 316-366

Worede, (1997). Genetic Diversity and Erosion-A Global Perspective. In book: Sustainable Development and Biodiversity 7, Chapter: 10, Publisher: Springer Cham Heidelberg New York Dordrecht London, Editors: M.R. Ahuja; S. Mohan Jain, pp263 - 294.

Yeshitila K., (2004). Prospects of forest genetic resources conservation, In: Proceeding of the public meeting on integrated forest policy development in Ethiopia, forum for environment, Institute of biodiversity, Addis Ababa.

Publisher's note: EScience Press remains neutral with regard to jurisdictional claims in published maps and institutional affiliations.

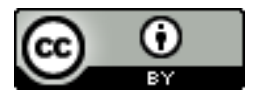

Open Access This article is licensed under a Creative Commons Attribution 4.0 International License, which permits use, sharing, adaptation, distribution and reproduction in any medium or format, as long as you give appropriate credit to the original author(s) and the source, provide a link to the Creative Commons license and indicate if changes were made. The images or other third-party material in this article are included in the article's Creative Commons license, unless indicated otherwise in a credit line to the material. If material is not included in the article's Creative Commons license and your intended use is not permitted by statutory regulation or exceeds the permitted use, you will need to obtain permission directly from the copyright holder. To view a copy of this license, visit http://creativecommons.org/licenses/by/4.0/.

(C) The Author(s) 2019. 